\section{DIARY}

JULY

International Association for Dental Research General Session

Date: 14-17 July 2010

Venue: Centre Convencions Internacional Barcelona (CCIB), Barcelona, Spain www.iadr.org/i4a/pages/index. cfm?pageid $=3854$

\section{BDA Clinical expert series:}

The 'bread and butter' issues of adhesive and aesthetic dentistry Date: 16 July 2010

Venue: Novotel St Pancras Hotel, London Email: events@bda.org www.bda.org/events

\section{AUGUST}

8th International Dental Ethics and Law Congress

Date: 18-20 August 2010

Venue: University of Helsinki, Finland www.ideals.ac

International Association for Disability and Oral Health 20th Congress

Date: 25-28 August 2010

Venue: Ghent, Belgium

www.iadh.org

\section{SEPTEMBER}

2010 FDI Annual World Dental Congress Date: 2-5 September 2010

Venue: Centro de Convencões da Bahia, Salvador da Bahia, Brazil

Email:congress@fdiworldental.org www.fdiworldental.org

Aesthetic dentistry for the GDP (Belfast) Date: 17 September 2010

Venue: Ramada, Belfast

Email: cappiah@rcseng.ac.uk www.fgdp.org.uk

Fall 2010 American Academy of Cosmetic Dentistry International Meeting/British Academy of Cosmetic Dentistry Annual Conference Date: 23-25 September 2010 Venue: Hilton London Metropole Hotel, London

Email: info@bacd.com www.aacdlondon.com

\title{
MEDICAL EMERGENCIES KIT WINS AWARD
}

Julie Burke and Kathryn Taylor from Leeds Dental Institute, University of Leeds, have been awarded the Yorkshire Proof of Commercial Concept Fund to help develop and commercialise Rescu$\operatorname{Pod}^{\mathrm{TM}}$.

RescuPod $^{\mathrm{TM}}$ consists of emergency drugs and essential emergency equipment; supporting algorithms for the dental team; online learning; management of expiry dates; medical emer- gency scenarios for in-house training; face to face training; and audit of and record of emergencies. It was launched at the British Dental Conference and Exhibition in Liverpool in May 2010.

Burke and Taylor have received three other awards in the last two years and have supplemented the launch of the RescuPod $^{\mathrm{TM}}$ prototype with educational seminars on medical emergencies.

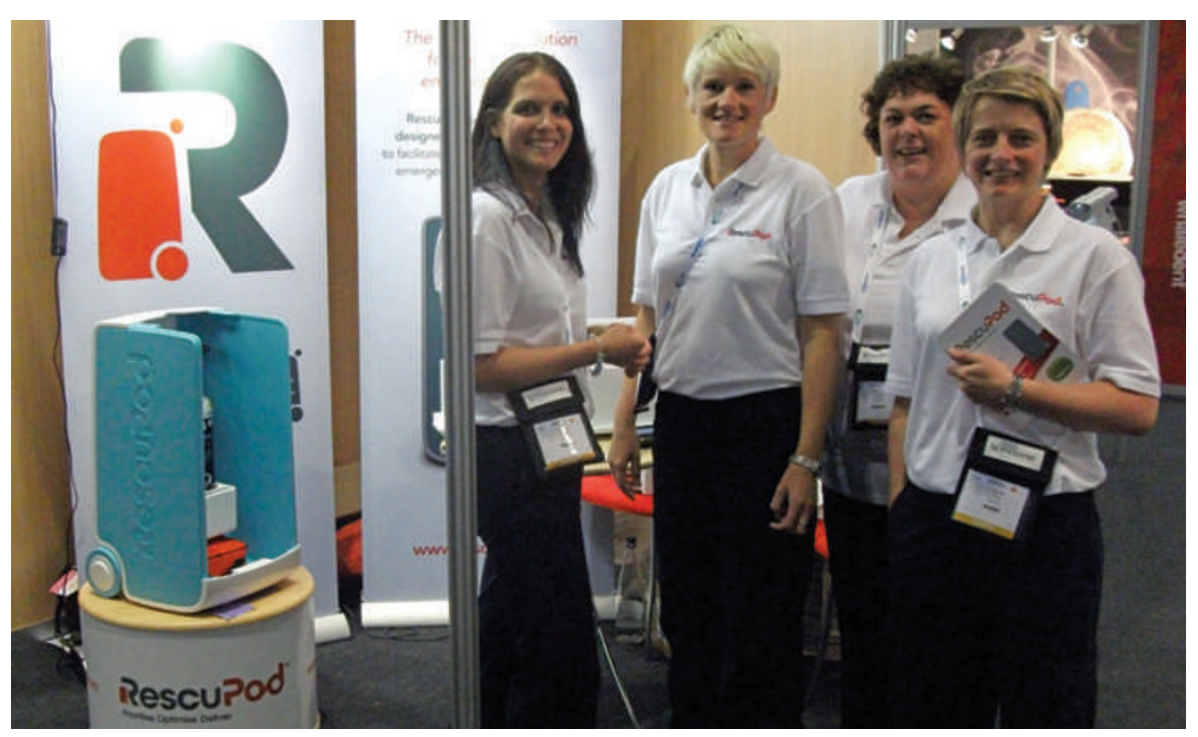

RescuPod team at BDA Conference, May 2010

\section{YORKSHIRE PRACTICE EMBRACES SOCIAL NETWORKING}

VI Dental Centre in Bridlington, East Yorkshire is embracing the rise in popularity of online social networking to attract new NHS patients.

VI Dental moved to a new six-surgery practice last year and launched a concerted marketing campaign in an area which, historically, has suffered from a shortage of NHS dentists. As well as press and radio advertising and distributing posters locally, VI Dental has created its own pages on Facebook and Twitter.

VI Dental's Facebook page provides 'fans' with regular updates of what is happening at the practice, while followers of 'Videntalcentre' on Twitter can access links to organisations like the Department of Health, the British Dental Association and

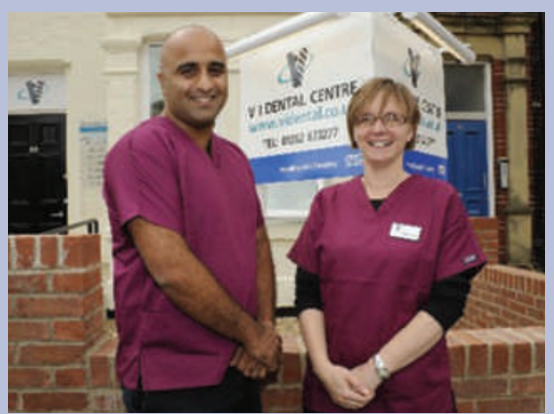

Dr Razwan Ilyas and Dr Maria van Reij of VI Dental

the British Dental Health Foundation. The Twitter feed also highlights events such as National Smile Month and the latest dental and related NHS news.

'For a long time people struggled to find an NHS dentist in Bridlington, which is perhaps why there's a perception that it's not even worth trying any more,' said Dr Razwan Ilyas, practice principal. 'We're keen to let people know we're here to help.' 